\title{
DAYA SAING KOPI INDONESIA DI PASAR AMERIKA SERIKAT: PENDEKATAN TWO STAGE DEMAND MODEL
}

\author{
Suharno ${ }^{1}$, Ahmad Syariful Jamil ${ }^{2}$, dan Resti Prastika Destiarni ${ }^{3}$ \\ ${ }^{1,2}$ DepatemenAgribisnis, Fakultas Ekonomi dan Manajemen, Institut Pertanian Bogor \\ ${ }^{3}$ Alumni Program Studi Agribisnis, Sekolah Pascasarjana Institut Pertanian Bogor \\ Email: suharno@apps.ipb.ac.id
}

\begin{abstract}
ABSTRAK
Dampak terbukanya pasar pada komoditas kopi dunia ditunjukkan dengan adanya kelebihan pasokan kopi di dunia. Di sisi lain, permintaan kopi dunia mengalami stagnasi bahkan pada beberapa negara importir mengalami penurunan, sehingga hal tersebut menyebabkan tingginyatingkatpersainganantarnegaraprodusen. Penelitian ini menggambarkan daya saing kopi Indonesia di pasar Amerika sebagai negara importir kopi terbesar. Pendekatan persamaan two-stage demand digunakan dalam penelitian ini. Persamaan pertama menganalisis permintaan Amerika menggunakan pendekatan persamaan linier double-log untuk mengidentifikasi respon harga secara umum pada perdagangan internasional. Persamaan kedua membedakan komoditas berdasarkan negara asal menggunakan pendekatan error correction almost ideal demand system (ECAIDS). Hasil penelitian menunjukkan bahwa perubahan harga teh sebagai produk substitusi dari kopi sangat berpengaruh terhadap permintaan kopi. Peningkatan pengeluaran impor Amerika akan meningkatkan pangsa ekspor Indonesia dengan nilai yang lebih kecil dibandingkan peningkatan negara lainnya. Kopi Indonesia memiliki hubungan komplementer dengan kopi Colombia, namun saling substitusi dengan negara lainnya. Indonesia memiliki daya saing yang relatif lemah dan untuk meningkatkan daya saingnya, Indonesia sebaiknya menurunkan biaya produksi dengan meningkatkan produktivitas dan kualitasnya melalui promosi.
\end{abstract}

Katakunci: daya saing, Indonesia, kopi, permintaan impor

\begin{abstract}
The impact of open market in world coffee comodity is reflected by the excess supply of world coffee. On the other hand, world coffee demand has faced stagnation even in some importer countries decreased, so that it causes high level of competition among producers. This study represents Indonesia's coffee competitiveness in United States market as the largest coffee importer. A twostage demand equation was employed in this study. The first equation analyzed the United state demand by using a double logarithmic-linear approach to identify price responses generally in international trade. The second equation distinguished commodities by the origin country using an error correction almost ideal demand system (ECAIDS) approach. The result implied that a change of tea price as a subtitute product of coffee strongly affected on coffee import demand. The increasing of US's import expenditure would increase Indonesia export share which is relatively smaller than the increasing of other countries. Indonesia coffee had complementary relationship with Colombia coffee; however, with other countries were subtituted each other. Indonesia had a relatively weak market competitiveness and to improve its market competitiveness, Indonesia should become more competitive in cost allocation by improving the productivity and its quality through promotion.
\end{abstract}

Keywords: competitiveness, Indonesia, coffee, import demand 


\section{PENDAHULUAN}

Kopi merupakan salah satu komoditas perkebunan yang memiliki peranan penting terhadap perekonomian Indonesia. Hal tersebut dikarenakan kopi merupakan komoditas nomor empat berkontribusi pada neraca perdagangan Indonesia. Indonesia sejak tahun 1984 merupakan negara pengekspor kopi terbesar ketiga di dunia setelah Brazil dan Kolombia (Kustiari 2007).

Sekitar $67 \%$ dari total produksi domestik merupakan ekspor sedangkan sisanya merupakan komoditas untuk dikonsumsi dalam negeri yang akan diolah menjadi kopi bubuk, kopi instan, dan mix coffee, ataupun disimpan sebagai carry over stock oleh pedagang dan pengekspor sebagai cadangan apabila terjadi gagal panen (Khumaira 2016).

Semakin terbukanya pasar internasional membuat negara yang memiliki keunggulan komparatif dapat saling bersaing. Hal tersebut menyebabkan produksi kopi dunia akan meningkat dan persaingan antar produsen semakin ketat, sedangkan permintaan dunia cenderung mengalami stagnan. Selain itu, produksi kopi Indonesia juga berfluktuasi dengan kecenderungan menurun. Hal tersebut terjadi salah satunya karena tanaman kopi sangat peka terhadap bencana embun upas dan kekeringan karena dapat meningkatkan serangan terhadap penyakit pada tanaman dan menggagalkan sebagian besar pertanaman kopi (Kustiari 2007).

Amerika Serikat merupakan salah satu negara tujuan ekspor komoditas kopi Indonesia. Namun sejak tahun 2012, volume ekspor kopi Indonesia ke Amerika Serikat mengalami penurunan (International Trade Centre 2015). Penurunan volume ekspor tersebut berpengaruh bagi Indonesia karena sebagian besar produksi kopi Indonesia diekspor. Di lain pihak, konsumsi kopi domestik masih tergolong rendah di sekitar 1 $065 \mathrm{~kg} / \mathrm{kapita} /$ tahun (Ditjenbun 2014).

Berdasarkan penelitian Kirnovos (2004) menyebutkan bahwa pangsa harga eksportir di pasar dunia meningkat setelah adanya liberalisasi perdagangan. Ada integrasi yang kuat antara pasar domestik dan pasar dunia. Hasil analisis pada jangka pendek menunjukkan terjadi peningkatan transmisi harga antara pasar dunia terhadap pasar eksportir sehingga harga domestik lebih cepat menyesuaikan fluktuasi harga dunia. Hal ini senada dengan penelitian Mohan dan Russel (2008), yang mana setelah adanya liberalisasi perdagangan kopi pada tahun 1980-an akibat bubarnya InternationalCoffee Agreement (ICA) menyebabkan persaingan pangsa pasar (share) pasar produsen kopi meningkat di pasar dunia. Hal tersebut membebaskan setiap negara untuk bersaing dengan keunggulan komparatif dan kompetitif yang dimilikinya.

Berdasarkan latar belakang tersebut, penelitian ini bertujuan menganalisis tingkat daya saing kopi Indonesia yang diekspor ke Amerika Serikat sebagai negara tujuan ekspor kopi utama.

\section{METODE PENELITIAN}

Data yang digunakan dalam penelitian ini berupa data deret waktu dan panel, dimana data tersebut digunakan untuk mengestimasi permintaan ekspor kopi Indonesia. Data tersebut antara lain volume dan nilai impor kopi Amerika dari beberapa negara yaitu Brazil, Kolombia, Guatemala dan Indonesia, nilai tukar dolar terhadap rupiah, Gross Domestic Product (GDP) Amerika, harga teh dunia dan harga kopi dunia. Data tersebut didapat dari berbagai sumber seperti UN Comtrade, FAO, BPS dan berbagai literatur terkait.

Pendekatan model dua tahap permintaan digunakan untuk menjawab tujuan penelitian. Persamaan linier double-log digunakan untuk mengidentifikasi respon harga secara umum pada perdagangan internasional. Berikut merupakan persamaan permintaan impor kopi Amerika:

$\mathrm{Y}_{\mathrm{t}}=\alpha_{0}+\alpha_{1} \mathrm{P}+\alpha_{2} \mathrm{GDP}+\alpha_{3} \mathrm{PT}+\alpha_{4} \mathrm{ER}+\varepsilon_{\mathrm{t}}(1)$

Dimana: $\mathrm{Y}_{\mathrm{t}}$ : volume impor kopi

Amerika (ton/t), P: harga kopi dunia (\$/kg), PT: harga teh dunia ( $\$ / \mathrm{kg})$, ER: Nilai tukar dolar US terhadap rupiah (Rp/US\$) dan $\mathrm{e}_{\mathrm{t}}$ : error term.

Persamaan error correction almost ideal demand system (ECAIDS) digunakan untuk membedakan kopi berdasarkan negara asal. Negara sumber ekspor kopi Amerika antara lain Indonesia, Brazil, Kolombia dan Guatemala. Sebelum mengestimasi model tersebut, beberapa uji seperti uji stasioner dan kointegrasi dilakukan sebagai tahapan memenuhi syarat perlu dan syarat cukup estimasi error correction mechanism (Juanda 2012 dan Nahrowi 2006). Secara matematis model ECAIDS yang digunakan dalam penelitian ini sebagai berikut (Deaton and 
Muelbauer 1980; Rifin 2010; dan Syafendi 2014)

$\Delta y_{\mathrm{i}}=\delta_{\mathrm{i}} \Delta \gamma_{\gamma \mathrm{it}-1}+\sum_{j=1}^{n} Y_{\mathrm{ij}} \Delta \log \mathrm{P}_{\mathrm{jt}}+\beta \Delta \log \frac{x}{p^{*}}+$

$\lambda_{\mathrm{i}} E C_{\mathrm{it}-1}+\mu_{\mathrm{t}}$

Dimana:

$\Delta$ : bentuk pembedaan, $E C_{\text {it-1: }}$ lag error correction term, $\mathrm{W}$ :pangsa ekspor negaranegara sumber ekspor kopi Amerika, x: total pengeluaran ekspor kopi Amerika dan $\mathrm{P}^{*}$ : corrected Stone Price Index

Model ECAIDS yang telah dibangun tersebut direstriksi dengan hambatan teoritis sistem permintaan seperti:

Adding up:

$\sum_{\mathrm{i}=1}^{\mathrm{n}} \alpha \mathrm{i}=1, \sum_{\mathrm{i}=1}^{\mathrm{n}} \mathrm{yij}=0, \sum_{\mathrm{i}=1}^{\mathrm{n}} \beta \mathrm{i}=0$

Homogeneity: $\sum_{i=1}^{n} y i j=0$

dan

simetry: $\mathrm{y}_{\mathrm{ij}}=\mathrm{y}_{\mathrm{ji}}$

Elastisitas harga uncompensated dan pengeluaran akan dihitung berdasarkan parameter yang telah diestimasi.Elasitisitas harga uncompensated $\left(e_{\mathrm{ij}}\right)$ dan elastisitas pengeluaran $\left(\eta_{\mathrm{i}}\right)$ dihitung berdasarkan:

Dimana:

$$
\begin{gathered}
\mathrm{e}_{\mathrm{ij}}=-\delta_{\mathrm{i}}+\left(\gamma_{\mathrm{ij}} / w_{\mathrm{i}}\right)+w_{\mathrm{i}} \\
\eta_{i}=1+\left(\beta_{\mathrm{i}} / w_{\mathrm{i}}\right)
\end{gathered}
$$

$\delta_{\mathrm{i}}:$ : knocker delta, dimana bernilai 1 apabila $\mathrm{i}=\mathrm{j}$ dan nol selain $\mathrm{i}=\mathrm{j}$ (Green and Laston 1991)

\section{HASIL DAN PEMBAHASAN}

Perkembangan Harga Kopi Dunia.

Saat ini, Industri kopi menunjukkan kondisi stagnasi, dimana terjadi kelebihan produksi kopi dunia. Kondisi tersebut diduga diakibatkan oleh semakin tingginya produksi dari negara produsen kopi, mekanisasi di Brazil, dilanggarnya Perjanjian Kopi Internasional dan diregulasi kebijakan atas kopi di beberapa negara produsen (Lewin et al 2003). Dari sisi permintaan, data FAO (2004) menunjukkan bahwa sebagai negara pengimpor kopi terbesar dunia, konsumsi kopi perkapita AS mengalami penurunan. Dimana rata-rata konsumsi perkapita kopi di AS menurun dari $6.7 \mathrm{~kg}$ pada tahun 1960an menjadi $4.1 \mathrm{~kg}$ pada tahun 1990an.

Fenomena stagnasi tersebut mengakibatkan harga kopi dunia tertekan. Hal ini sesuai dengan data harga kopi dunia yang dipublikasikan oleh world bank, dimana sejak tahun 1970an harga kopi dunia memiliki kecenderungan yang terus menurun.

Penurunan tersebut akan mempengaruhi kehidupan jutaan orang terutama di negara berkembang produsen kopi (Feleke 2005). Oleh karena itu, penurunan permintaan dan tekanan dari dalam akibat dampak penurunan pendapatan bagi petani kopi menyebabkan tingkat kompetisi negara produsen dunia menjadi semakin tinggi.

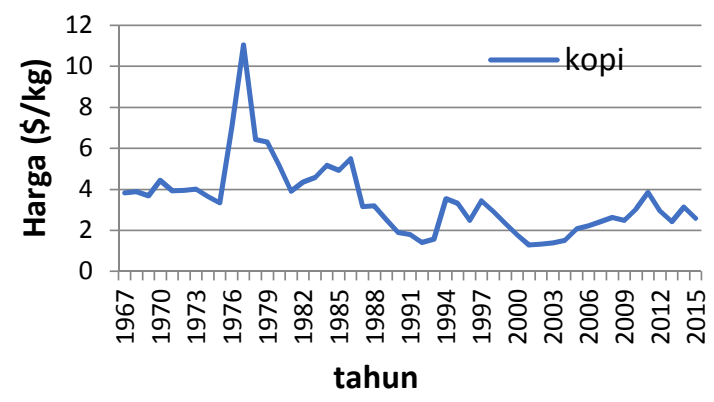

Faktor-Faktor yang Memengaruhi Volume Impor Kopi Amerika. Berdasarkan Tabel 1 menunjukkan hasil estimasi persamaan permintaan kopi Amerika dalam jangka panjang. Nilai F-statistik yang didapatkan menunjukkan bahwa secara simultan (bersama-sama) faktor-faktor independen berpengaruh nyata terhadap volume impor kopi Amerika. Masing-masing faktor pengaruh telah sesuai dengan teori ekonomi dan telah signifikan berpengaruh nyata pada taraf alpha $5 \%$, kecuali faktor nilai tukar.

Dalam jangka panjang, volume impor kopi Amerika dipengaruhi secara positif oleh pendapatan Amerika (GDP) dan harga teh dunia, sedangkan dipengaruhi secara negatif oleh harga kopi itu sendiri.

Besaran nilai parameter pendapatan Amerika tersebut menunjukkan bahwa komoditas kopi di amerika merupakan barang normal $\left(\mathrm{E}_{\mathrm{I}}>0\right)$, bahkan lebih merupakan barang pokok. Dimana, nilai parameter sebesar 0.354 berarti ketika terjadi peningkatan $1 \%$ pendapatan masyarakat Amerika akan meningkatkan volume impor kopi sebesar $0.354 \%$. Selain itu, nilai parameter harga kopi menunjukkan bahwa kopi impor merupakan komoditas yang inelastis $\left(E_{p}<|1|\right)$, sedangkan hubungan antara kopi dan teh menunjukkan hubungan yang substitusi dengan nilai elastisitas silang sebesar $0.354\left(\mathrm{E}_{\mathrm{XY}}>0\right)$.

\section{Permintaan Impor Kopi Amerika berdasarkan negara sumber ekspor}

Selain mengestimasi elastisitas jangka panjang, penelitian ini menggunakan model ECAIDS untuk mengakomodasi elastisitas 
harga dan pendapatan jangka pendek berdasarkan sumber ekspor kopi. Besaran nilai elastisitas tersebut disajikan pada Tabel 2.

Tabel 1

Faktor-faktor yang memengaruhi volume impor kopi Amerika

\begin{tabular}{lccc}
\hline \multicolumn{1}{c}{ Variabel } & Koefisien & T-Hitung & P-value \\
\hline Harga kopi & $-0.188668^{*}$ & -2.463606 & 0.0207 \\
GDP & $0.354892^{*}$ & 2.448732 & 0.0214 \\
Amerika & & & \\
Harga teh & $0.525018^{*}$ & 3.680571 & 0.0011 \\
Nilai tukar & 0.354892 & -1.689697 & 0.1030 \\
Rp/US\$ & & & \\
C & 11.12122 & 10.69942 & 0.0000 \\
\hline R-squared & 0.410762 & \\
Adjusted R-squared & 0.320110 & \\
F-statistic & 4.531194 & \\
Prob(F-statistic) & 0.00654 & \\
\hline Keterangan * &
\end{tabular}

Keterangan: * signifikan pada $\alpha=5 \%$

Tabel 2 menunjukkan bahwa semua nilai elastisitas harga sendiri dari masingmasing negara memiliki tanda yang sesuai dengan teori ekonomi dan elastis $\left(\mathrm{E}_{\mathrm{P}}>|1|\right)$. Dimana Indonesia merupakan negara dengan nilai elastisitas terbesar ( $\mathrm{E}_{\mathrm{P}}$ : 1.804). Besarnya nilai elastisitas harga Indonesia tersebut mengindikasikan kopi Indonesia relatif kurang berdaya saing dibandingkan dengan negara lainnya. Hal ini sejalan dengan Sano (2014) yang menyatakan bahwa jika suatu produk inelastis maka konsumen cenderung loyal terhadap produk tersebut. Tingginya elastisitas kopi Indonesia mengindikasikan bahwa kopi yang berasal dari Indonesia cenderung memiliki konsumen yang kurang royal.

Berdasarkan nilai elastisitas harga silang menunjukkan bahwa Indonesia memiliki hubungan substitusi dengan Brazil dan Guatemala, sedangkan hubungan komplemen ditunjukkan dengan Kolombia. Besaran nilai $\mathrm{E}_{\mathrm{XY}}$ sebesar -0.089 berarti peningkatan $1 \%$ harga kopi ekspor Indonesia akan menurunkan pangsa ekspor kopi dari Kolombia. Dengan kata lain, kopi Indonesia dan Kolombia saling melengkapi dalam memenuhi permintaan impor kopi Amerika.

Selain itu, tabel 2 juga menunjukkan nilai elastisitas pengeluaran, dimana semua kopi dari negara sumber ekspor merupakan barang normal $\left(\mathrm{E}_{\mathrm{I}}>0\right)$. Indonesia memiliki nilai elastisitas pengeluaran paling rendah dibandingkan dengan negara sumber ekspor lainnya. Nilai elastisitas sebesar 1.101 berarti peningkatan $1 \%$ total pengeluaran impor Amerika akan meningkatkan pangsa ekspor kopi Indonesia sebesar $1.101 \%$.

\section{SIMPULAN DAN IMPLIKASI KEBIJAKAN}

Fakta yang menunjukkan bahwa kopi merupakan barang pokok dan memiliki nilai elastisitas harga yang inelastis memberikan signal bahwa pangsa impor kopi Amerika masih menjadi tujuan yang menarik bagi negara produsen kopi dunia. Namun, besarnya potensi tersebut tidak dapat dimanfaatkan dengan baik oleh Indonesia.

Dengan kata lain, Indonesia relatif kurang memiliki daya saing dibandingkan dengan kopi dari negara lainnya. Hal ini dicerminkan oleh nilai elastisitas harga yang lebih elastis dibandingkan dengan negara lainnya. Besarnya nilai tersebut mengindikasikan bahwa kopi Indonesia kurang terdiferensiasi, sehingga mengakibatkan konsumen terhadap kopi Indonesia kurang loyal. Selain itu, berdasarkan nilai elastisitas pengeluaran menunjukkan bahwa Indonesia hanya akan memperoleh pangsa ekspor paling kecil dibandingkan dengan negara produsen kopi lain apabila Amerika meningkatkan total pengeluaran ekspornya.

Berdasarkan kondisi tersebut, strategi yang perlu dilakukan oleh Indonesia adalah meningkatkan tingkat keunggulannya dengan menurunkan harganya. Hal ini didasarkan pada teori yang menyatakan bahwa penurunan harga pada produk yang bersifat elastis akan meningkatkan total pendapatannya (Salvatore 2005). Salah satu cara yang dapat dilakukan

Tabel 2.

Faktor-faktor yang memengaruhi volume impor kopi Amerika

\begin{tabular}{lccccc}
\hline & \multicolumn{3}{c}{ Price Elasticities } & Expenditure \\
\hline & Brazil & Kolombia & Guatemala & Indonesia & Elasticities \\
\hline Brazil & -1.303 & & & & 1.146 \\
Kolombia & 0.045 & -1.637 & & & 1.197 \\
Guatemala & -0.159 & 0.211 & -1.355 & & 1.195 \\
Indonesia & 0.282 & -0.089 & 0.133 & -1.804 & 1.101 \\
\hline
\end{tabular}


Indonesia untuk menurunkan harganya adalah dengan meningkatkan produktivitasnya. Apabila produktivitas meningkat secara otomatis akan menurunkan harganya dan menjadikan kopi Indonesia juga semakin kompetitif. Selain itu, dengan menurunnya harga akan juga sekaligus menekan balik pangsa kopi dari Brazil dan Guatemala.

Strategi lain yang dapat dilakukan oleh Indonesia adalah lebih menitikberatkan pada upaya dalam mendeferensiasikan kopi Indonesia di tingkat konsumen. Salah satunya dengan melakukan kegiatan promosi dalam rangka memperkenalkan kopi-kopi khas daerah seperti kopi gayo, kopi toraja dan lainlain. Hal tersebut perlu dilakukan karena dengan semakin terdeferensiasinya kopi Indonesia di tingkat konsumen maka akan menurunkan jumlah produk substitusinya dan sekaligus akan membuat kurva permintaan yang dihadapi oleh produsen kopi Indonesia semakin inelastis. Namun pada akhirnya, upaya-upaya tersebut juga membutuhkan kekonsistenan dalam mengimplementasikan berbagai kebijakan.

\section{DAFTAR PUSTAKA}

Deaton, A and Muelbauer, J. 1980. An Almost Ideal Demand System. The American Economic Review, 70(3), pp. 312-326.

[Ditjenbun] DirektoratJenderal Perkebunan. 2014. Data Statistik [internet].[diacu 15 Mei 2017]. Tersediadari: http://ditjenbun.pertanian.go.id/statis30-neraca.html.

Green, A and Julian M. Alston.1991.American Journal of Agricultural Economics, 73(3), pp. 874-875.

[ITC] Internasional Trade Center. 2015. International trade in goods statistics byproduct group [internet]. [diakses 15 Mei 2017].
Tersediadari:http://www.trademap.org/

Country_SelProduct_TS.aspx.

Juanda, B., dan Junaidi. 2012. Ekonometrika Deret Waktu. Bogor: IPB Press.

Khumaira. 2016. Transmis Harga Kopi Antara Pasar Indonesia dan Pasar Tujuan Ekspor Utama. [Tesis]. Institut Pertanian Bogor.

Kirnovos E. 2004. The Impact of Coffee Market Reforms on Producer Prices andPrice Transmission. Policy Research Working Paper. Washington DC(US): The World Bank Development Reseach Group Trade Team.

Kustiari R. 2007. Perkembangan Pasar Kopi Dunia danImplikasinyaBagiIndonesia. Forum Penelitian Agro Ekonomi, 25(1) : $43-55$.

Mohan S, Russell B. 2010. Modelling Thirty Five Years of Coffee Prices in Brazil,Guatemala dan India. Dundee Discussion Papers in Economics studies,Inggris (ENG).

Nachrowi, N.D., dan Usman, H. 2006. Pendekatan Populer dan Praktis Ekonometrika untuk Analisis Ekonomi dan Keuangan. Depok: LP-FEUI.

Rifin, A. 2010. An Analysis of Indonesia's Palm Oil Position in the World Market: A Two-stage Demand Approach. Oil Palm Industry Economic Journal, 10(1), pp.33-42.

Salvatore, D. 2005. Ekonomi Manajerial Buku 1. Jakarta: Salemba Empat.

Sano, N, Tamura, S, Yada, K, and Suzuki, T. 2014. Evaluation of Price Elasticity and Brand Loyalty in Milk Products. Procedia Computer Science, 35(2014), pp. 1482-1487.

Syafendi, M.R. 2014. Analisis Posisi Karet Alam Indonesia di Pasar Karet Alam China. [Tesis]. Institut Pertanian Bogor. 